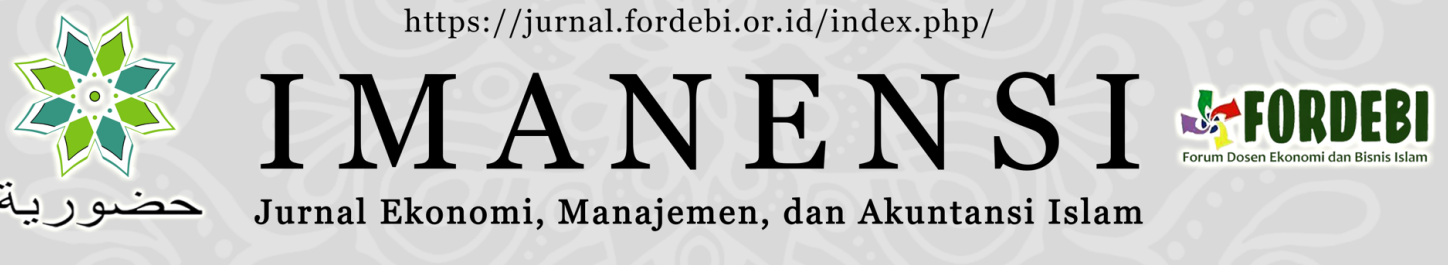

\title{
MENGGALI NILAI-NILAI ETIKA SYARIAH PEMBIAYAAN MUDHARABAH
}

\author{
Rizky Maulidaa,1, Abdul Gafurb,2*, Isna Yuningsihc,3 \\ a,b,c Universitas Mulawarman, Jalan Kuaro Kampus Gunung Kelua Samarinda, 75119 Indonesia. \\ 1rizkymaulida3367@gmail.com; 2abdul.gafur@feb.unmul.ac.id*; 3isna.yuningsih@feb.unmul.ac.id \\ *Corresponding author
}

\begin{tabular}{ll}
\hline INFO ARTIKEL & Abstrak: Menggali Nilai-Nilai Etika Syariah Pembiayaan \\
IMANENSI & Mudharabah. Tujuan penelitian ini adalah untuk memahami \\
kolume 6 & mudarabah bank syariah. Penelitian menggunakan paradigma \\
Nomor 1 & Islam melalui adopsi pendekatan fenomenologi Islam, melalui \\
Halaman 1-14 & wawancara terhadap tiga orang pelaku perbankan BNI Syariah \\
Malang, Maret 2021 & cabang Samarinda dan satu orang ahli fikih. Hasil penelitian \\
ISSN: 2339-1847 & menunjukkan bahwa kesadaran etika syariah pelaku \\
e-ISSN: 2683-9968 & perbankan berdasar pada nilai hasanah, dakwah, dan \\
& matematika akhirat dalam pemberian layanan pembiayaan \\
Kronologi Artikel: & mudarabah, melalui kepatuhan terhadap norma syariah yang \\
Tanggal Masuk: & mengatur akad mudarabah. \\
$\mathbf{4}$ Desember 2020 & Abstract: Exploring the sharia Ethical Values of \\
Tanggal Revisi: & Mudharabah Financing. The purpose of this research is to \\
18 Januari 2021 & understand the awareness of sharia ethics in banking actors in \\
Tanggal Diterima: & Islamic bank mudarabah financing. This research uses the \\
$\mathbf{1 0}$ Februari 2021 & Islamic paradigm through the adoption of the Islamic \\
Kata Kunci: & phenomenology approach, through interviews with three BNI \\
Dakwah; & Syariah banking actors in the Samarinda branch and one \\
Etika Syariah; & jurisprudence expert. The results show that the awareness of \\
Hasanah; & sharia ethics in banking actors is based on the value of hasanah, \\
Matematika Akhirat; & da'wah, and the hereafter mathematics in providing mudarabah \\
Keywords: & financing services, through compliance with sharia norms that \\
Da'wah; & govern the mudarabah contract.
\end{tabular}

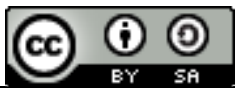

Disitasi sebagai: Maulida, R., Gafur, A., \& Yuningsih, I. (2021). Menggali Nilai-Nilai Etika Pembiayaan Mudarabah. IMANENSI: Jurnal Ekonomi, Manajemen, dan Akuntansi Islam, 6(1), 1-14. https://doi.org/10.34202/imanensi.6.1.2021.1-14

\section{PENDAHULUAN}

Keunikan ajaran Islam adalah mengajarkan manusia untuk melakukan praktik ekonomi berdasarkan etika syariah, termasuk pada bank berbasis syariah. Kondisi tersebut menjadikan bank syariah berperan sebagai entitas bisnis sekaligus sebagai entitas dakwah yang secara normatif perlu memperhatikan masalah etika dalam pelaksanaan aktivitasnya. Berbagai penelitian terkait etika syariah khususnya etika kerja syariah menyimpulkan bahwa etika kerja syariah dapat meningkatkan komitmen organisasi (Anik and Arifuddin 2003; Rokhman 2014; Salahudin et al. 2016), perubahan organisasi (Anik and Arifuddin 2003; Dewi and 
Bawono 2008), kepuasan kerja (Rokhman 2014; Siddiq and Hadjiah 2019), kinerja karyawan (Syarif, Rahmawati, and Fasa 2019), kualitas kerja karyawan serta dan produktivitas karyawan (Syarif et al. 2019).

Etika syariah juga dapat meningkatkan nama baik akuntan (Mahdavikhou and Khotanlou 2012) serta kejujuran, keadilan, kebajikan, dan semangat etik (Furqani, Laldin, and Mulyany 2016). Secara konseptual, nilai etika syariah juga digunakan dalam perumusan tujuan filosofis bank syariah yang menghasilkan kriteria penilaian kesehatan bank syariah (Triyuwono 2011). Terdapat pula konsep dan penelitian pada etika bisnis syariah (Juliana, Sulthan, and Fathir 2019; Nanji 1991; Nerdin and Ratnawati 2015; Niswatin et al. 2014) yang konsepnya berbeda dengan teori etika utilitarian (Desjardins 2014; Harrison 2005) maupun etika konfusianisme (Usman 2016).

Penelitian ini bermaksud untuk memahami kesadaran etika syariah pada bankir bank syariah berdasarkan pendekatan fenomenologi Islam (Niswatin et al. 2014). Penelitian ini berbeda dengan beberapa penelitian berdasarkan pendekatan fungsional yang melakukan pengujian asosiasi etika syariah dengan konsep lain dalam dunia bisnis (Amalia, Riani, and Julia 2016; Anik and Arifuddin 2003; Dewi and Bawono 2008; Juliana et al. 2019; Laeheem 2018; Nerdin and Ratnawati 2015; Rokhman 2014; Salahudin et al. 2016; Siddiq and Hadjiah 2019; Soemaryani 2018; Syarif et al. 2019). Penelitian ini juga sekaligus menegasikan konsep etika utilitarian dan konfusianisme (Desjardins 2014; Harrison 2005; Usman 2016) dengan mencoba memformulasikan bukti empiris nilai etika syariah (Nanji 1991; Niswatin et al. 2014; Triyuwono 2011) berdasarkan pengamatan pada kesadaran bankir dalam aktivitas pembiayaan mudarabah di bank syariah. Pembiayaan mudarabah memiliki skema yang lebih kompleks dibandingkan dengan jenis pembiayaan lainnya. Kompleksitas tersebut dapat berimplikasi pada keunikan perilaku bankir bank syariah dalam menerapkan etika syariah, sehingga pembiayaan mudarabah sangat tepat dijadikan sebagai unit analisis.

\section{METODE}

Penelitian ini berdasarkan pada paradigma Islam melalui adopsi pendekatan fenomenologi Islam (Niswatin et al. 2014) dengan beberapa modifikasi pada tahapan pengumpulan dan analisis data. Modifikasi fenomenologi Islam sebagai berikut: 1) analisis tekstural dengan pertanyaan awal tentang makna etika syariah, untuk menghasilkan noema, 2) analisis struktural untuk menghasilkan noesis (bracketing dibatasi pada kesadaran yang berorientasi pada etika syariah), 3) analisis intensional untuk memahami cara noesis membentuk noema, 4) reduksi eidetik untuk menghasilkan esensi, dan 5) sintesis dengan bantuan informan ahli yang memahami fikih mudarabah.

Peneliti mengumpulkan data melalui observasi dan wawancara dengan pelaku perbankan yaitu pegawai BNI Syariah cabang Samarinda pada tanggal 2 September sampai 1 November 2019. Pelaksanaan observasi pada kantor informan yang waktunya bersamaan sebelum, selama, dan setelah wawancara mendalam dengan informan. Peneliti melakukan wawancara mendalam dengan Bapak IK, Bapak AD dan Bapak PR (pegawai BNI Syariah yang mengurusi pembiayaan mudarabah) dan Bapak JS (ahli fikih mudarabah).

\section{HASIL DAN PEMBAHASAN}

Analisis tekstural menunjukkan pemahaman informan bahwa etika syariah dalam pembiayaan mudarabah terkait dengan noema "menjaga norma-norma", "SOP langsung dari Allah", "rambu-rambu", dan "metode ekonomi Rasulullah", sebagaimana ungkapan informan berikut ini. 


\begin{abstract}
"Kalau saya mengartikan etika syariah itu ya... tanggung jawab untuk \{menjaga norma-norma\} syariah.” (Bapak IK)

"Etika syariah itu aturan yang harus kita patuhi dan laksanakan, kalau untuk kita sendiri sih yang bekerja di bank syariah, etika syariah juga ya.. sebagai \{rambu-rambu\} mengingat bahwa di bank syariah ini kan banyak sekali hal-hal yang harus diperhatikan, ada tantangan tersendiri lah pokoknya." (Bapak AD)

"Misalnya nih, apakah hanya selama bekerja di bank syariah saja kita dituntut harus jujur, sedangkan etika kita diluar tidak harus jujur, nggak kan? dan seperti yang kita ketahui, bank syariah ini kan merupakan bank yang menggunakan \{metode ekonomi Rasulullah\}, dimana kita ada aturan sendiri nggak asal ngejalanin aktivitas begitu saja." (Bapak PR)
\end{abstract}

Pertanyaan peneliti yang mengarahkan pada makna etika syariah memunculkan kesadaran tekstural informan. Kesadaran tekstural tersebut memudahkan peneliti untuk secara langsung menggali kesadaran struktural dengan melakukan bracketing pada istilah unik yang diungkapkan informan. Analisis kesadaran struktural pada Bapak IK menunjukkan bahwa Bapak IK memaknai "menjaga norma-norma" sebagai "pembeda dan dasar" seperti ungkapannya berikut ini.

"Norma-norma syariah itu kan sebagai aturan syariah ya mbak.. khususnya bagi bank syariah yang tentunya pula sebagai \{pembeda dan dasar\} dari bank syariah mulai dari keharusan untuk tidak menggunakan riba dalam setiap transaksi, tidak adanya unsur gharar, bertanggung jawab, amanah dan hasanah.” (Bapak IK)

Pembeda dan dasar dari bank syariah diartikan oleh Bapak IK yaitu sebagai "akad" yang ada pada bank syariah, karena akad ini berfungsi sebagai kriteria kebenaran transaksi yang sesuai dengan prinsip syariah, seperti pernyataannya:

"Perumpamaannya seperti ini, kita (bank syariah) dan bank koven samasama menjual ayam goreng, tapi ayam goreng yang kita (bank syariah) jual punya keharusan di mana saat dipotong kita wajib untuk membaca "bismillahirrahmanirrahim", sedang-kan di bank konven tidak, nah bacaan ini diumpamakan sebagai "akad" dan akad ini lah yang menjadi pembeda antara kita (bank syariah) dan bank konven, akad ini pula yang memang sesuai dengan prinsip syariah, kan kalau kita bertransaksi harus ada akadnya, dan karena sesuatu yang memang wajib hukumnya kan harus kita penuhi." (Bapak IK)

Penjelasan lebih lanjut diartikan Bapak Iskandar terhadap norma-norma syariah sebagai keharusan untuk tidak menggunakan riba, tidak adanya unsur gharar, bertanggung jawab, amanah, dan hasanah. Berikut ungkapan Bapak IK.

"Tidak mengandung riba itu kita jalankan ya sesuai prinsip bank syariah, kan bank syariah pakai prinsip bagi hasil bukan bunga, riba itu kan tambahan yang disyaratkan sejak awal peminjaman uang (kredit), 
sedangkan kita kan nggak gitu, toh bank syariah kan bukan tempat untuk \{meminjamkan uang (utang)\}." (Bapak IK)

"Ya gimana ya, kalau di bank konven itu kan setiap yang datang (nasabah) tujuannya pasti untuk pinjam uang, ya jadi kita kayak hanya sebatas untuk pemenuhan target kerja saja lah nggak ada hal lainnya. Nah lain halnya kalau di bank syariah ini mbak, kalau di bank syariah ini kan kita banyak akadnya dan semua itu disesuaikan sama keperluan nasabah." (Bapak IK)

"Kalau untuk contoh unsur gharar itu, yang pasti kan setiap pengajuan pembiayaan kita harus tau dong tujuan dan latar belakang si yang mengajukan pembiayaan ini gimana, harus jelas dong semuanya nggak mungkin kan kita ngasih sembarangan tanpa mencari tau dan memeriksa kelengkapan persyaratan si calon pembiayaan ini, yang mana di dalam proses pembiayaaan mudharabah ini setiap tahapannya mulai dari permohonan pembiayaan hingga tahap pencairan benar-benar kita perhatikan, selain untuk memperkecil risiko ya.. kita lakukan untuk ini juga menghindari gharar ini." (Bapak IK)

"Amanah kan sebuah titipan yang dipercayakan kepada kita, kalau dalam konteks pekerjaan kan amanah dari pimpinan kepada saya untuk memegang jabatan ini dengan melaksanakan tugas atau pekerjaan yang diberikan, sedangkan tanggung jawab itu kan timbul dari pribadi masingmasing kita, misal tanggung jawab saya kepada Allah ya berarti saya harus menjalankan setiap pekerjaan saya sesuai dengan aturan syariah karena memang itu sebagai pertanggung jawaban saya kepada Allah nanti." (Bapak IK)

Bapak IK mengartikan hasanah sebagai salah satu bentuk dari norma syariah. Menurutnya, hasanah di Bank BNI Syariah digunakan sebagai prinsip utama yang harus dipegang teguh oleh setiap pegawai. Hasanah juga mengharuskannya untuk meniatkan sesuatu dengan ikhlas. Nilai hasanah tersebut membuat Bapak IK memiliki identitas untuk selalu menebarkan kebaikan baik pada masyarakat (nasabah) maupun antar pegawai di Bank BNI Syariah Cabang Samarinda. Berikut merupakan pernyataan Bapak IK mengenai hasanah.

"Untuk hasanah sendiri di BNI Syariah, hasanah itu kita gunakan sebagai prinsip utama yang harus dipegang teguh oleh setiap pegawai, jadi kayak hasanah life style gitu. Hasanah sendiri memiliki artian yaitu kebajikan, dalam hal ini kebajikan bukan dan tidak hanya berorientasi pada dunia saja tetapi juga pada akhirat. Hasanah itu kan berarti kita harus \{berbuat baik\} kepada siapa saja, kepada diri kita sendiri juga termasuk dan niatnya harus ikhlas, karena insya allah kalau kita ikhlas ya semua kebaikan itu akan kembali ke kita juga kok. Hasanah ini sendiri membuat saya sebagai pegawai bank syariah (BNI Syariah) memiliki identitas untuk selalu menebarkan kebaikan kepada masyarakat (nasabah) maupun kepada seluruh pegawai di sini” (Bapak IK).

Bapak IK mengartikan berbuat baik sebagai suatu tindakan yang bermanfaat dan tidak merugikan bagi orang lain dan hal tersebut termasuk dalam menjaga norma-norma syariah seperti ungkapannya. 
"Berbuat baik berbuat baik ini kan dalam artian tindakan yang bermanfaat dan tidak merugikan orang lain, nah hal sederhana seperti ini sebenarnya termasuk dalam menjaga norma-norma syariah tadi”.

Selain kesadaran tekstural "menjaga norma-norma", Bapak IK juga memahami bahwa etika syariah meluputi juga sikap profesional dengan istilah "SOP langsung dari Allah".

"Etika syariah itu kan hal yang pastinya tidak terlepas dari tanggung jawab seorang bankir di bank syariah ya mbak.. dimana dalam menjalankan tugas dan tanggung jawab ini kita selalu berusaha bersikap profesional dengan cara bekerja sesuai \{SOP langsung dari Allah\}" (Bapak $I K)$.

Bapak IK mengartikan SOP langsung dari Allah sebagai perintah dari Allah yang terdapat dalam al-Qur'an maupun al-Hadis mengenai perbuatan boleh atau pun tidak boleh.

"SOP langsung dari Allah ini kan berarti perintah yang Allah turunkan melalui firman-Nya dalam al-qur'an maupun hadits, yang mana di dalam Al-Qur'an dan hadits ini sendiri kan banyak sekali aturan yang menuntun kita terkait apa yang harus kita kerjakan dan apa yang tidak boleh kita kerjakan, salah satunya ya pelaksanaan etika syariah ini” (Bapak IK).

Bapak IK memiliki prinsip tersendiri untuk menjalankan setiap tanggung jawabnya. Dalam setiap aktivitasnya, beliau selalu menanamkan prinsip ibadah salah satu bentuk SOP dari Allah. Bapak IK beribadah menggunakan prinsip "matematika akhirat" dalam bekerja di bank syariah, yang membedakan saat bekerja di bank konvensional dengan prinsip matematika dunia.

"Dalam diri saya, saya menanamkan prinsip ibadah dalam aktivitas apapun khususnya dalam bekerja. Ini adalah prinsip utama yang membedakan saya saat bekerja di bank konvensional dan bank syariah. Dulu saya bekerja ya hanya sebatas untuk mencari uang dan apa pun yang saya kerjakan intinya haruslah menghasilkan keuntungan materi. Pokoknya kalau di bank konven ini yang saya cari ya matematika dunia lah mbak, beda sama di bank syariah yang kita cari ya \{matematika akhirat; yang hasilnya memang langsung dari Allah nggak bisa dihitung. Ya... saat kita bekerja di bank syariah dan saat semua yang kita kerjakan di niatkan untuk ibadah maka rejeki, kemudahan, kebahagiaan, dan tentunya ketenangan juga akan mengikuti kita dengan sendirinya intinya semua sudah Allah atur sedemikian baiknya untuk kita, ya jadi kita nggak perlu khawatir, yang penting kita kerja aja terus niatkan semua karena ibadah".

Pendalaman melalui analisis struktural, informan Bapak AD memberikan penjelasan tentang "rambu-rambu" sebagai berikut.

"Untuk rambu-rambu ini sendiri ya seperti \{pelindung\} kita, artinya kalau kita tidak mematuhi atau kita langgar ya berarti sama saja kita tidak taat." (Bapak $A D$ ) 
"Untuk makna pelindung, kita misalkan aja seperti kepatuhan lalu lintas lah ya.. kalau mbak rizky matuhin lalu lintas dengan cara memakai helm, punya sim, stnk, bpkb dll pasti dong mbak rizky merasa aman dan tenang, nah begitu juga dengan etika syariah. Kalau kita patuhi dan laksanakan pasti dong kita merasa aman dan tenang dalam artian sudah memenuhi tanggung jawab kita dalam bekerja di bank syariah.” (Bapak AD)

Bapak AD mengartikan bahwa tantangan bank syariah karena sampai dengan saat ini masih dinilai sama oleh masyarakat umum, yang mana proses dan akad yang ada pada bank syariah sangatlah berbeda.

"Ya.. tantangan kita sebagai bank syariah, kan sampai dengan saat ini orang mikirnya bank syariah itu sama aja kayak bank konven namanya aja beda tapi sebenarnya isinya sama aja kok, padahal kan secara \{proses dan akad; jelas berbeda." (Bapak AD)

Bapak AD memaknai perbedaan antara bank konvensional dan bank syariah terletak pada akad dan prosesnya. Akad yang ada pada bank syariah merupakan hal yang wajib dilaksanakan pada setiap transaksi. Sementara, proses pembiayaan yang ada pada bank syariah juga tidak terlepas dari aturan syariah.

"Nah selain bedanya di akad dan dalam bentuk barang, yang membedakan bank syariah itu adalah prosesnya. Akad-akad yang ada pada bank syariah ini kan memang kita gunakan pada setiap transaksi di bank syariah. Kalau di bank syariah prosesnya harus sesuai syariah salah satunya barang yang diperjualbelikan tidak boleh ada unsur yang membahayakan/merugikan misalnya senjata tajam, nggak mungkin dong kita berikan kebutuhan nasabah yang seperti itu, makanya kalau kita ini menyediakan barang yang memang benar-benar jelas bentuk dan manfaatnya, kalau hanya uang saja kan kita nggak tau itu dipergunakan untuk apa." (Bapak AD)

Bapak AD melaksanakan etika syariah sebagai bentuk pertanggungjawaban kepada Allah dengan bekerja secara jujur, teliti, disiplin, dan amanah. Selain itu, Bapak AD juga menjelaskan bahwa tugasnya di bank syariah bukan hanya bekerja tetapi juga berdakwah dengan cara memberikan informasi kepada keluarga maupun masyarakat umum untuk meninggalkan bank konvensional dan beralih ke bank syariah. Berikut ungkapannya.

"Ya.. tugas kita di bank syariah ini bukan hanya bekerja tetapi juga berdakwah dengan cara memberikan informasi kepada keluarga maupun masyarakat umum untuk meninggalkan bank konven dan beralih ke bank syariah yang tentunya disertai dengan alasan-alasan yang mendukung bahwa berhijrah ke bank syariah itu bukan hanya untuk menghindari riba, tetapi juga sebagai bentuk pertanggungjawaban kita kepada Allah." (Bapak $A D$ )

Kesadaran dakwah juga dimaknai oleh informan Bapak PR. Kesadaran dakwah Bapak PR berawal dengan penjelasannya tentang metode ekonomi Rasulullah, seperti ungkapannya. 
"Untuk metode ekonomi Rasulullah, ini tentunya berkaitan dengan apa yang mesti diterapkan di bank syariah, prinsip apa kiranya yang beliau gunakan saat berdagang seperti jujur, adil, amanah, transparan serta tidak mengurangi dalam takaran dan timbangan. Etika syariah inilah yang tidak dimiliki atau tidak di jadikan prinsip bagi bank konven, bank konven sendiri kan seperti yang kita tahu telah \{melanggar etika syariah\}." (Bapak PR)

"Kadang kita memang punya kesulitan untuk me-maintenance nasabah mudarabah yang tidak bersedia menyediakan laporan keuangan setiap bulan, nah dengan etika syariah ini kita punya poin-poin sendiri untuk diperhatikan. Contoh, kita dapat menjelaskan kepada nasabah bahwa dalam pembiayaan mudarabah sangat dibutuhkan mengenai laporan keuangan tersebut dengan alasan agar tidak terjadi kesalahan dalam pembagian nisbah bagi hasil, nah.. poin penting dari etika syariah di sini adalah kita senantiasa harus menyampaikan semua hal yang memang berkaitan dengan kepentingan kedua belah pihak. Seperti yang saya katakan tadi bahwa kita memang harus kembali pada \{metode ekonomi Rasulullah\} saat berdagang, prinsip tersebutlah yang memang harus kita contoh dan praktekan guna sebagai bentuk tanggung jawab kita sebagai bank syariah." (Bapak PR)

Bapak PR menjelaskan metode ekonomi Rasulullah wujud dari prinsip ibadah yang kemudian diterjemahkan sebagai life balance. Bapak PR menyadari keharusan untuk menyeimbangkan tanggung jawab sebagai umat muslim dan juga sebagai pegawai bank syariah yang profesional.

"Kita di BNI Syariah ini kan didorong dan dimotivasi untuk melaksanakan (life balance) yaitu dengan menyeimbangan antara tanggung jawab sebagai umat muslim yang taat dan juga tanggung jawab sebagai pegawai bank syariah yang profesional. Kalau untuk contohnya ya.. seperti berdakwah, dengan mengajak masyarakat untuk menggunkan produk-produk bank syariah".

Ungkapan kesadaran tekstural informan Bapak IK, Bapak AD, dan Bapak PR melalui "menjaga norma-norma", "rambu-rambu", dan "metode ekonomi Rasulullah" dibentuk oleh noesis berupa "hasanah", "dakwah", dan "matematika akhirat". Berikut ini adalah analisis intensional untuk memahami cara noesis membentuk noema.

Hanasah diartikan oleh Bapak IK sebagai bentuk dari norma syariah. Norma syariah sendiri merupakan bentuk kesadaran tekstural Bapak IK dalam menjelaskan etika syariah. Ungkapan berikut ini menegaskan kesadaran tentang pentingnya prinsip hasanah.

"Untuk hasanah sendiri di BNI Syariah, hasanah itu kita gunakan sebagai prinsip utama yang harus dipegang teguh oleh setiap pegawai, jadi kayak hasanah life style gitu." (Bapak IK)

Bapak IK mengartikan hasanah melalui keharusan berbuat baik. Sementara berbuat baik memiliki makna bahwa suatu tindakan yang bermanfaat dan tidak merugikan orang lain dan hal tersebut dalam rangka menjaga norma-norma syariah. 
"Berbuat baik berbuat baik ini kan dalam artian tindakan yang bermanfaat dan tidak merugikan orang lain, nah hal sederhana seperti ini sebenarnya termasuk dalam menjaga norma-norma syariah tadi." (Bapak IK)

Informan PR juga memahami hasanah sebagai kebaikan dan bagian dari implementasi nilai-nilai syariah.

"Hasanah itu artinya kebaikan ya.. kebaikan dalam artian yang luas." (Bapak PR)

"Menurut saya saat kita bekerja diselimuti dengan nilai-nilai syariah seperti hasanah ini, maka di dalam diri kita yang sesungguhnya kita cari itu bukanlah profit dalam bentuk rupiah melainkan sebuah ridha dan berkah dari Tuhan." (Bapak PR)

Dengan demikian, hasanah merupakan bentuk kesadaran struktural informan (Bapak IK dan Bapak PR). Hasanah merupakan kesadaran terdalam yang menghasilkan kesadaran tekstural informan yang berujung pada pemaknaan etika syariah pada aktivitas pembiayaan mudarabah.

Kesadaran dakwah sebagai kesadaran struktural pun berawal dari kesadaran tekstural informan Bapak AD yang memaknai etika syariah sebagai rambu-rambu.

"Ya.. tugas kita di bank syariah ini bukan hanya bekerja tetapi juga berdakwah..." (Bapak $A D)$

Ungkapan Bapak AD tersebut merupakan penjelasan dari pemaknaannya tentang tanggung jawab bankir dalam menerapkan etika syariah dalam proses pembiayaan mudarabah. Seperti halnya Bapak PR yang mencontohkan dakwah sebagai pelaksanaan life balance.

"Kita di BNI Syariah ini kan didorong dan dimotivasi untuk melaksanakan life balance..." (Bapak PR)

Bapak PR menjelaskan life balance sebagai uraian pemaknaan metode ekonomi Rasulullah dan etika syariah.

“...sedangkan etika kita di luar tidak harus jujur, nggak kan? dan seperti yang kita ketahui, bank syariah ini kan merupakan bank yang menggunakan \{metode ekonomi Rasulullah\}" (Bapak PR).

Pemaknaan life balance Bapak PR muncut tatkala dia melaksanakan ibadah dakwah dalam pembiayaan mudarabah.

"...Kalau untuk contohnya ya.. seperti berdakwah, dengan mengajak masyarakat untuk menggunakan produk-produk bank syariah” (Bapak PR).

Terakhir, matematika akhirat juga merupakan kesadaran struktural dalam pembiayaan mudarabah. Kesadaran tersebut nampak pada pernyataan Bapak IK saat menjelaskan prinsip ibadah. Matematika akhirat merupakan kesadaran struktural Bapak IK selain hasanah. Matematika akhirat adalah kesadaran terdalam Bapak IK saat menjelaskan SOP langsung dari Allah sebagai kesadaran tekstural beliau. 
"SOP langsung dari Allah ini kan berarti perintah yang Allah turunkan melalui firman-Nya dalam al-qur'an maupun hadits, yang mana di dalam al-Qur'an dan hadis." (Bapak IK)

"...beda sama di bank syariah yang kita cari ya matematika akhirat yang hasilnya memang langsung dari Allah nggak bisa dihitung”. (Bapak IK)

Ungkapan tersebut menunjukkan bahwa Bapak IK menanamkan prinsip ibadah sebagai salah satu bentuk SOP dari Allah. Bapak IK beribadah menggunakan prinsip "matematika akhirat" dalam bekerja di bank syariah, yang membedakan saat bekerja di bank konvensional dengan prinsip matematika dunia.

Gambar 1 menunjukkan hasil analisis intensional dan reduksi eidetik terhadap noema yang menghasilkan noesis berupa hasanah, dakwah, dan matematika akhirat.

Pemahaman terhadap kesadaran terdalam informan dalam membentuk kesadaran terluar informan menghasilkan untuk menghasilkan esensi dalam tahapan eidetik reduction, yaitu 1) Bankir bank syariah menyadari bahwa prinsip hasanah merupakan nilai mendasar dalam memberikan layanan pembiayaan mudarabah; 2) Bankir bank syariah menganggap bahwa pekerjaannya dalam proses pembiayaan mudarabah merupakan dakwah mengajak kepada umat untuk menjauhi riba: 3) Bankir bank syariah merasakan keikhlasan dalam bekerja di bank syariah karena adanya internalisasi prinsip metematika akhirat dalam aktivitas sehari-hari.

Tahapan akhir penelitian ini adalah penyajian sintesis dengan bantuan informan ahli yang memahami fikih akad mudarabah. Penyajian sintesis tidak hanya sebatas pada apa yang pengalaman informan, tetapi juga berdasarkan pada eksplorasi kandungan Alquran dan Hadis. Diskusi dilakukan dengan Bapak JS yang merupakan adalah seorang dosen dalam bidang fikih muamalah. Bapak JS menuturkan bahwa etika syariah merupakan hal yang patut diperhatikan dalam praktik bank syariah. Menurutnya, bank syariah yang sesuai dengan etika syariah adalah bank yang berjalan sesuai dengan prinsip-prinsip keislaman.

"Etika syariah sebenarnya tidak hanya untuk bank syariah tetapi juga untuk semua kegiatan. Dalam pelaksanaan perbankan, bank syariah yang sesuai dengan etika syariah adalah bank yang berjalan sesuai dengan prinsip-prinsip keislaman" (Bapak JS).

Pelaksanaan etika syariah dalam proses pembiayaan mudarabah harus berjalan sesuai dengan prinsip-prinsip mudarabah, yaitu salah satu pihak bertindak sebagai penyedia dana (shahibul maal) dan pihak lainnya bertindak sebagai pengelola dana (mudarib). Selain itu, juga harus sesuai dengan prinsip utamanya yaitu profit sharing.

"Prinsip mudarabah itu kan jelas, etika syariah itu tentunya harus sesuai dengan prinsip-prinsip mudharabah di mana dalam praktiknya harus ada 2 pihak yang bertindak sebagai penyedia dana (shahibul maal) dan sebagai pengelola dana (mudarib), di samping itu kita juga harus melihat apakah memang BNI Syariah ini sudah sesuai dengan skema pembiayaan dimana porsi keuntungan dibagi sesuai nisbah dan kerugian akan ditanggung oleh penyedia dana kecuali memang karena kesalahan pengelola dana" (Bapak JS). 
Keunggulan dari proses pembiayaan mudarabah terletak pada unsur adil dan jujur. Prinsip adil dan jujur ini sangat penting karena terdapat hak dan kewajiban pada masing-masing pihak. Bapak JS menyebutkan pula Alquran surat al-Maidah ayat 8 yang artinya sebagai berikut.

"Hai orang-orang yang beriman hendaklah kamu jadi orang-orang yang selalu menegakkan (kebenaran) karena Allah, menjadi saksi dengan adil. Dan janganlah sekali-kali kebencianmu terhadap sesuatu kaum mendorong kamu untuk berlaku tidak adil. Berlaku adillah, karena adil itu lebih dekat kepada takwa. Dan bertakalah kepada Allah, sesungguhnya Allah Maha Mengetahui apa yang kamu kerjakan" (Alquran surat al-Maidah: 8).

Bapak JS juga menekankan pentingnya kesadaran individu dengan ungkapan berikut ini.

"Kalau sistemnya syariah tapi individunya nggak syariah kan nggak bisa juga. Islam itu pada hakikatnya adalah sebuah sistem, di mana kita sebenarnya dituntut untuk menjalankan sebuah sistem tersebut. Sama halnya dengan bank syariah, sistem di bank syariah itu sudah dibuat sedemikian sesuai dengan syariah tapi kalau pegawainya nggak melaksanakan sesuai syariah ya sama aja.. ketika sistem pada bank syariah sesuai dengan prinsip syariah maka pegawainya pun harus melaksankan sistem tersebut sesuai dengan prinsipnya." (Bapak JS)

Wawancara mendalam dengan Bapak JS menegaskan bahwa kesadaran etika syariah pada pembiayaan mudarabah berdasarkan pada nilai hasanah, dakwah, dan matematika akhirat. Hal tersebut menunjukkan pentingnya kesadaran individu bankir bank syariah seperti yang diungkapkan Bapak JS. Kesadaran individu tersebut merupakan kesadaran dakwah yang dapat mendorong kesalahen pengelola dana mudarabah sebagaimana prinsip etika syariah yang dijelaskan Bapak JS. Nilai hasanah, dakwah, dan matematika akhirat merupakan perwujudan dari Alquran surat al-Maidah ayat 8 yang memerintahkan orang-orang yang beriman untuk menjadi orang-orang yang selalu menegakkan kebenaran karena Allah.

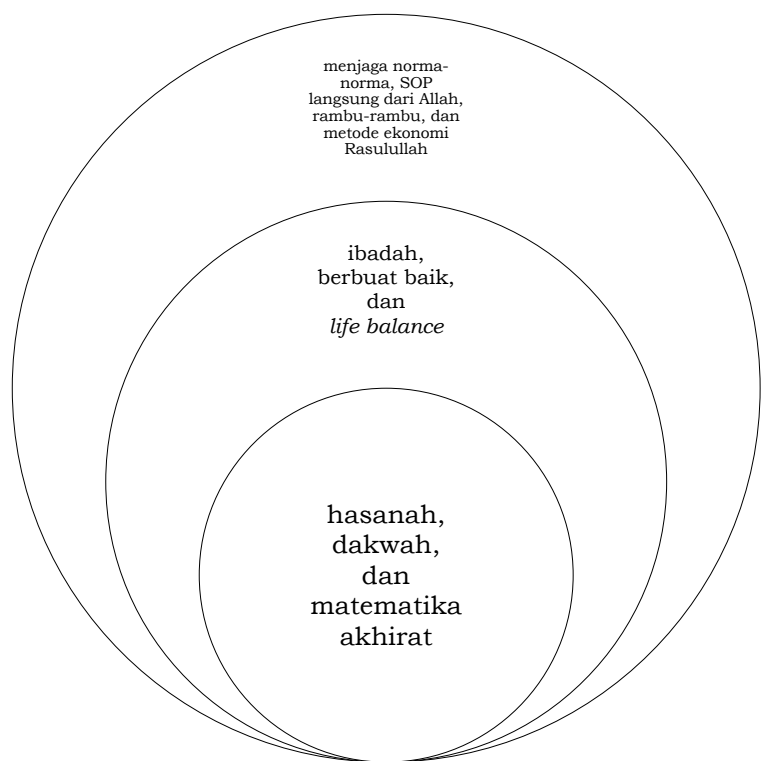

Gambar 1. Hasil Analisis Intensional 
Berdasarkan hasil analisis eidetic reduction dan diskusi mendalam dengan Bapak JS, dapat disimpulkan bahwa kesadaran etika syariah bankir BNI Syariah Cabang Samarinda berdasarkan pada kesadaran hasanah, dakwah, dan matematika akhirat. Kesadaran hasanah merupakan kesadaran bankir untuk berbuat baik dalam proses pembiayaan mudarabah. Perbuatan baik menghasilkan kepatuhan terhadap norma-norma syariah dalam pembiayaan mudarabah.

Kesadaran dakwah merupakan kesadaran bankir bahwa pelayanan dalam proses pembiayaan mudarabah adalah upaya untuk memberikan pemahaman kepada masyarakat tentang pentingnya permodalan usaha yang bebas riba. Kesadaran ini nampak pada perilaku bankir bank syariah yang menjadikan etika syariah sebagai rambu-rambu dan metode ekonomi Rasulullah melalui keseimbangan hidup (life balance) sebagai penyampai kebenaran ajaran muamalah Islam.

Kesadaran matematika akhirat adalah kesadaran bankir bahwa pekerjaan dalam proses pembiayaan mudarabah merupakan bentuk ibadah karena berdasarkan pada petunjuk (standar operating procedure-SOP) langsung dari Allah dalam rangka menghindari riba. Definisi kesadaran hasanah, dakwah, dan matematika akhirat tersebut secara sederhana dapat diilustrasikan Gambar 2.

Dengan demikian, etika syariah bankir bank syariah dalam pembiayaan mudarabah merupakan etika yang berdasarkan pada kesadaran hasanah, dakwah, dan matematika akhirat dalam pemberian layanan pembiayaan mudarabah melalui kepatuhan terhadap norma syariah yang mengatur akad mudarabah.

Penelitian ini menghasilkan suatu pola etika syariah yang berbeda dengan penelitian yang melakukan pengujian etika syariah secara asosiatif dan fungsional (Anik and Arifuddin 2003; Dewi and Bawono 2008; Mahdavikhou and Khotanlou 2012; Rokhman 2014; Salahudin et al. 2016; Siddiq and Hadjiah 2019; Syarif et al. 2019). Penelitian ini berdasarkan pada data empiris, yang secara konseptual tidak sama persis dengan konsep kejujuran, keadilan, kebajikan, dan semangat etik (Furqani et al. 2016) dan pendekatan etika syariah mutazila (Nanji 1991). Meskipun menjadikan bank syariah sebagai situs yang sama, temuan dan fokus penelitian ini juga berbeda konsep nilai etika syariah dalam formulasi pengukuran kinerja bank syariah (Niswatin et al. 2014) dan dalam perumusan tujuan filosofis bank syariah (Triyuwono 2011). Terakhir, penelitian ini menegasikan teori etika utilitarian (Desjardins 2014; Harrison 2005) maupun etika konfusianisme (Usman 2016).

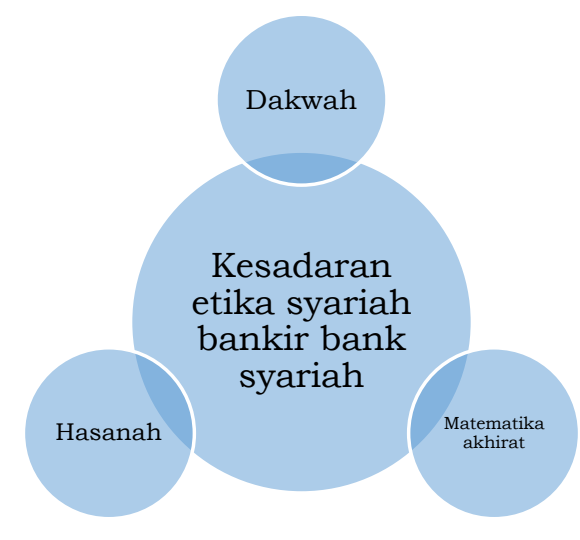

Gambar 2. Etika syariah bankir bank syariah 


\section{SIMPULAN}

Penelitian ini menghasilkan gambaran empiris nilai yang mendasari etika syariah pada bankir Bank BNI Syariah Cabang Samarinda. Etika syariah pada bankir tersebut berdasarkan pada nilai hasanah, dakwah, dan matematika akhirat. Keterbatasan penelitian ini berkaitan dengan lingkup penelitian yang dilaksanakan di bank Syariah, yang secara langsung sudah menerapkan nilai Syariah dalam menjalankan usahanya. Ada baiknya untuk penelitian selanjutnya, dilakukan konstruksi mengenai praktik etika Syariah pada tataran usaha yang tidak hanya jenis usaha Syariah.

\section{REFERENSI}

Amalia, Ima, Westi Riani, and Aaan Julia. 2016. "The Influence of Religiosity Values on Happiness with Islamic Consuming Ethics as Moderator Variable." Procedia - Social and Behavioral Sciences 219:76-83. doi: 10.1016/j.sbspro.2016.04.044.

Anik, Sri, and Arifuddin. 2003. "Analisis Pengaruh Komitmen Organisasi Dan Keterlibatan Kerja Terhadap Hubungan Antara Etika Kerja Islam Dengan Sikap Perubahan Organisasi." Jurnal Akuntansi Dan Auditing Indonesia (JAAI) 7(2):159-81.

Desjardins, Joseph. 2014. An Introduction to Business Ethics. Fifth. Mc Graw Hill.

Dewi, Sari Suasana, and Icuk Rangga Bawono. 2008. "Analisis Pengaruh Etika Kerja Islam Terhadap Sikap Karyawan Bagian Akuntansi Dalam Perubahan Organisasi (Studi Kasus Pada Bank Umum Non Syariah Di Wilayah Eks Karesidenan Banyumas Jawa Tengah)." Jurnal Akuntansi Dan Auditing Indonesia (JAAI) 12(1):65-78.

Furqani, Hafas, Mohamad Akram Laldin, and Ratna Mulyany. 2016. "Good Finance: Integration of Ethics and Shariah in Islamic Finance." International Journal of Islamic Business Ethics 1(2):121-30. doi: 10.30659/ijibe.1.2.121-130.

Harrison, Mike R. 2005. An Introduction to Business and Management Ethics. New York: Palgrave Macmillan.

Juliana, J., M. Adib Sulthan, and Muhammad Fathir. 2019. "Islamic Business Ethics: Case Study of Puspa Sharia Micro Business Actors in Bank Indonesia West Java Region in Bandung 2017." Review of Islamic Economics and Finance 2(1):31-37. doi: 10.17509/rief.v2i1.17674.

Laeheem, Kasetchai. 2018. "Relationships between Islamic Ethical Behavior and Islamic Factors among Muslim Youths in the Three Southern Border Provinces of Thailand." Kasetsart Journal of Social Sciences 39(2):305-11. doi: $10.1016 /$ j.kjss.2018.03.005.

Mahdavikhou, Mahdi, and Mohsen Khotanlou. 2012. "New Approach to Teaching of Ethics in Accounting 'Introducing Islamic Ethics into Accounting Education." Procedia - Social and Behavioral Sciences 46:131822. doi: 10.1016/j.sbspro.2012.05.294.

Nanji, Azim. 1991. "Islamic Ethics." Pp. 106-18 in A Companion to Ethics, edited by P. Singer. Blackwells Oxford.

Nerdin, and Alifah Ratnawati. 2015. "Tingkat Customer Loyality Berbasis Islamic Business Ethic and Brand Image." 2nd Conference in Business, Accounting, and Management (CBAM) 2(1):382-91.

Niswatin, Iwan Triyuwono, Nurkholis, and Ari Kamayanti. 2014. "Islamic Values of Islamic Bank Underlying Performance Assessment." Research Journal of Finance and Accounting 5(24):106-13. 
Rokhman, Wahibur. 2014. "Islamic Work Ethic As an Antecedent of Work Outcomes: A Study of Islamic Microfinance in Central Java, Indonesia." QIJIS (Qudus International Journal of Islamic Studies) 2(1):82-97.

Salahudin, Shahrul Nizam bin, Siti Sarah binti Baharuddin, Muhammad Safizal Abdullah, and Abdullah Osman. 2016. "The Effect of Islamic Work Ethics on Organizational Commitment." Procedia Economics and Finance 35(October 2015):582-90. doi: 10.1016/s2212-5671(16)00071-x.

Siddiq, Andhika Mochamad, and Hady Siti Hadjiah. 2019. "Islamic Work Ethic and Employee Engagement, Variable to Improve Employee Job Satisfaction." The International Journal of Business Review (The Jobs Review) 2(1):9-18. doi: 10.17509/tjr.v2i1.17771.

Soemaryani, Imas. 2018. "Model for Improving the Employee Productivity through Islamic Leadership and Internalization of Islamic Work Ethic in Sharia Tourism (Study on Sharia Hotels in Bandung)." Jurnal Bisnis Dan Manajemen 19(2):122-39. doi: 10.24198/jbm.v19i2.207.

Syarif, Ahmad Hazas, Afida Rahmawati, and Muhammad Iqbal Fasa. 2019. "The Effect of Islamic Work Ethic and Productivity on Work Quality Through The Employee Performance." Review of Islamic Economics and Finance 2(2):92101. doi: 10.17509/rief.v2i1.22375.

Triyuwono, Iwan. 2011. "ANGELS: Sistem Penilaian Tingkat Kesehatan Bank Syari'ah." Jurnal Akuntansi Multiparadigma 1-21.

Usman. 2016. "Confucianism Ethic and the Spirit of Capitalism." DINIKA: Academic Journal of Islamic Studies 1(2):177-87. doi: 10.22515/dinika.v1i2.110. 
Halaman ini sengaja dikosongkan 